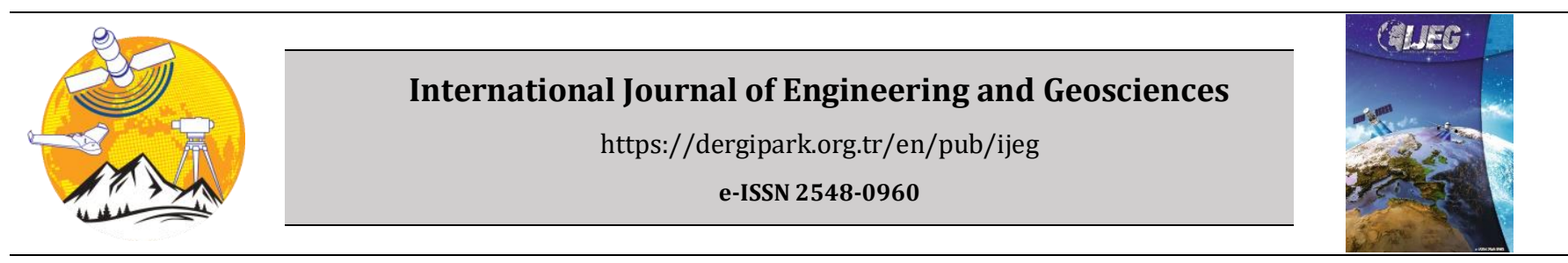

\title{
Assessment of the completion of the forest cadastre considering the legal grounds, collaboration, and the use of technology: The case of Turkey
}

\author{
Orhan $\operatorname{Ercan}^{* 1}$, Nur Kemalettin Toker ${ }^{2}(\mathbb{D}$ \\ 1International Federation of Surveyors (FIG), Ankara, Turkey \\ ${ }^{2}$ General Directorate of Land Registry and Cadastre, Ankara, Turkey
}

\author{
Keywords \\ Forest \\ Forest Cadastre \\ Forest Delimitation \\ Private Sector Involvement \\ Sustainable Development Goals
}

\begin{abstract}
The forests are among the natural resources that have important economic, environmental, and cultural functions. However, global problems, which have been increasing each passing day, such as industrialization, increasing urban population, global climate change, and destruction of biodiversity also threaten forests. The first condition for the protection of forests and carrying out forestry activities is the demarcation of forest boundaries and the registration of the forests. The forest cadastre has remained a major issue on Turkey's agenda for years. In this article, the process beginning with the demarcation of the forest boundaries until their registration in the land registry system was reviewed and assessed considering the institutional and legal frameworks and amendments, technology use, the collaboration between institutions, and the participation of the private sector. As a result of this collaboration, the General Directorate of Land Registry and Cadastre and the General Directorate of Forestry together with the participation of the private sector completed the forest cadastre of $6,246,845$ hectares in eight years between 2010 and 2017. Moreover, the registration of $82.52 \%$ of these lands was completed. Besides, solutions were proposed for other countries experiencing the same problem within the framework of the United Nations Sustainable Development Goals.
\end{abstract}

\section{INTRODUCTION}

The latest data covering the forest assets in Turkey was published in 2015. The area of the forest lands was stated to be 21,537,091 hectares in 2010. This figure was stated as 22,342,935 hectares in 2015 (TFA 2019). According to the forest cadastre works completed in 2017 , the area of the forest lands was found to be about $24,000,000$ hectares.

According to the General Directorate of Forestry (GDF) Strategic Plan 2010-2014, the ownership of 99\% of the forests in Turkey belongs to the state. The forest important economic, environmental, and cultural functions. About $10 \%$ of the population of Turkey lives in forest villages or the villages in the vicinity of the forests, where forest resources provide a vital contribution to the livelihood of the villagers. Urban dwellers have a growing interest in forests, particularly due to their biodiversity and environmental and social functions. (FAO 2015). lands, which cover $27.6 \%$ of the area of Turkey, have

Within the framework of Goal 15 of the United Nations' 2030 Agenda for Sustainable Development Goals, several studies have been carried out to provide sufficient incentives for the protection, restoration, and promoting sustainable use of forests, sustainable management of all forest types, stopping deforestation, restoring degraded forests by rehabilitation by 2030 . Moreover, the proposed solutions for the forest-related issues were brought to the agenda of the international community.

The primary condition for the proper execution of the forest regime in line with modern forestry principles is the demarcation of the boundaries of the lands considered forests and their cadastre (Çağlar 2004). Forests are subject to registration in accordance with Article 11 of Forest Law No. 6831. The land is registered with the attribute of "forest" in the name of the Treasury. The registration can only be made after the completion of the forest cadastre. Forest cadastre covers the demarcation of the boundaries of the forests, the 
application works for the previous forest demarcation or cadastral operations following the new legislation, and registration of the lands whose boundaries are determined by the implementation of Article 2 of the Forest Law to the land registry system. The lands where the forest cadastre works and the application works were recently completed should be registered to the land registry system after solving the problems arising from the registration legislation of the General Directorate of Land Registry and Cadastre (GDLRC) and those arising from the private registered properties within the forest boundaries (GDF Strategic Plan 2013-2017).

In Turkey, the modern forest cadastre works started in 1937, when Forest Law No. 3116 entered into force. It was observed that forest demarcation and forest cadastre works were addressed in separate articles in the relevant Law. Article 10 of the Law stipulated that the forest demarcation works should be completed within five years. while Article 21 of the same Law stipulated that the cadastral works should be completed within 10 years. However, the forest cadastre works could not be completed until today due to various problems encountered in the implementation of this Law and its related regulations (Gençay 2012; GDF Strategic Plan 2010-2014).

The fact that the forest cadastre and ownership problems have not been resolved yet were based on the following reasons: property cadastre and forest cadastre works being carried out by different authorities (Ayanoğlu 1992; Anbar 2004; Gençay 2012); rural cadastre works being carried out faster than forest cadastre works due to these difficulties in forest demarcation (Ayanoğlu 1992); the relations between the administration and the local people negatively affected due to ownership disputes in many places; carrying out forestry activities in areas whose boundaries have not yet been demarcated; intensive political and social pressures; frequent amendments in legislation; insufficient number of staff; lack of expert staff; deficiencies in technology transfer and applications; that the economic, social, and educational status of the forest villagers are lower; that the forestry activities are open to nature; that the administration traditionally has centralized and instruction-oriented approaches; that the forest villagers constitute the economically poorest part of Turkey and they are generally forest-dependent for their livelihoods, etc. (GDF 2006).

On the other hand, the following solutions were proposed to ensure the protection and the safety of the forest assets: demarcation of the forests and registering them to the land registry system as soon as possible; facilitating the registration of the previous forest cadastre, which could not be registered to the land registry system, by cadastral renewal and update works (Köktürk 2004; Anbar 2004) carrying out property cadastre and forest cadastre works by a single administration (Anbar 2004); establishment of Forest Cadastre Information System (Köktürk 2004), and using modern technologies (Yalçın 2012; Livia et al. 2012).

The completion of the forest cadastre has become a corporate policy of the GDF. Also, this policy was included as a strategic goal in the annual reports and strategic plans of the institution. Annual Report 2011 states that it was aimed to complete the demarcation and cadastral procedures of all forest lands by the end of 2014 , as well as, to complete the land registry procedures of the forest lands whose cadastre was completed and finalized. Moreover, it was stated that completing the forest cadastre procedures and registration of these lands to the land registry system was set as the ultimate goal in the Annual Report 2015 and Annual Report 2017 of the institution. On the other hand, in the GDF Strategic Plan 2010-2014, the goal was stated as completing the forest cadastre by the end of 2014. The issue was addressed in the GDF Strategic Plan 2010-2014 as the completion of the demarcation and cadastral procedures of the forest lands, as well as, the completion of the land registration procedures of the forest lands whose cadastre was completed and finalized. It was also stated that significant legal and technical infrastructure works had been completed. The GDF Strategic Plan 2010-2014 stated the strategic goal as the complete elimination of the forest cadastre issue together with GDLRC by using state-of-the-art technologies at the end of the plan period. Moreover, the establishment of a "Forest Cadastre Information System", where all digital and textual data about the permits granted for the lands considered forest and not forest were kept together, was also included in the goals of the GDF.

In a study on the factors that delayed the forest cadastre works and the solution of forest cadastre issue, Gençay (2012) stated that lack of coordination between institutions, insufficient attention paid by the administration, shortage of trained personnel and equipment were the most significant factors among others. However, the most significant conclusion of this study was that the problem could be solved by facilitating the collaboration of the institutions.

The present study evaluates the organizational structures, legal infrastructures, the uses of technology of GDLRC and GDF in terms of collaboration within the scope of the solution of the forest cadastre issue, examines the solution methodology, reveals the results of the implementation of the method, offers suggestions for the joint projects between institutions.

\section{INSTITUTIONS AND THEIR DUTIES}

\subsection{The General Directorate of Forestry}

The first initiatives in the forestry sector in Turkey started in 1839. In 1924, the Ministry of Agriculture was established and the GDF was affiliated. Forestry activities were carried out by GDF, which was affiliated with various ministries until today. GDF was affiliated with the Ministry of Agriculture and Forestry as per the Presidential Decree No. 4 dated 2018.

GDF carries out the forest cadastre activities through the Department of Forest Cadastre and Ownership. The major duties of the Department of Forest Cadastre and Ownership can be listed as follows: performing forest cadastre procedures; carrying out works and procedures regarding the determination and evaluation of the areas taken out of forest boundaries; settlement of various disputes regarding state forests; carrying out works and procedures regarding the inspection and control of 
forests belonging to parties other than the state; carrying out works for granting permission, usufruct, and easement for forest areas; following up and finalizing the land registry procedures of the lands for which the forest cadastre works are completed, etc.

\subsection{General Directorate of Land Registry and Cadastre}

The First Land Registry Organization was established in 1847, and it served under various names until 1923 when the Turkish Republic was declared. In 1924, the "General Directorate of Land Registry" was established, and the cadastre branch was added in 1925. GDLRC, which attained its current organizational structure in 1936, was affiliated with the Ministry of Finance, then it was affiliated with the Ministry of Justice in 1939. GDLRC had been affiliated with the Prime Ministry in 1951 and served 51 years in this organization until it was affiliated with the Ministry of Public Works and Settlement in 2002. Finally, it was affiliated with the Ministry of Environment and Urbanization in 2011 and has been providing service under this Ministry.

The Presidential Decree No. 4 dated 2018, defined the following tasks for GDLRC:

i. Carrying out cadastre procedures in Turkey and to follow up the changes,

ii. Ensuring renewal and updating of the cadastre plans and performing the related control and auditing services;

iii. Ensuring the reliability of land registries, which is under the responsibility of the state, regularly,

iv. Performing all kinds of contractual and noncontractual registration transactions related to real estates,

v. Following up and controlling the changes on the registers,

vi. Ensuring the protection of records and documents by archiving,

vii. Establishing a geodetic network, spatial information system infrastructure, and map production monitoring centre for the production of large-scale cadastral and topographic maps.

\section{LAWS AND REGULATIONS ON FORESTRY}

\subsection{Laws and Regulations on the Forestry Procedures}

Land Law dated 1858, which was the first regulation on forests, stated that forests were public property and could not be subject to private property. On the other hand, Article 24 of the Forest Regulations dated 1870 prohibited the acquisition of the state-owned forests and forests specific to villages and towns through prescription.

The regulations on the forests are inspired by the principles of protection of forests and ensuring their sustainability, governance, and execution of the forest regime by the State, and demarcation of the forest boundaries within this framework. During the Republic period, forestry regulations were made after the Civil Code, which entered into force in 1926. The first comprehensive regulation on forestry was Forest Law No. 3116 dated 1937. This Law aimed to demarcate the boundaries of the State forests, to survey the forest lands and register them to the land registry system, and to complete these procedures within 5 years. The task of demarcation and mapping of the forests was assigned to the Forest Cadastre Commissions affiliated with the GDF. The "Regulation on the Demarcation and Registration of Forests" entered into force as the technical principles for the demarcation of the forests. The demarcation of the state-owned forests could not be completed in 5 years due to several challenges in terms of surveying, etc. According to the provisions of Law No. 4785, which entered into force in 1945, all forests belonging to real or legal persons were expropriated.

Law No.5653 and Law No. 5658, which were entered into force in 1950, amended the regulations. According to these laws, the forest lands that were subjected to private ownership in the forest demarcation/cadastre works carried out until 1945, were taken out of forest boundaries. With Law No. 6831 dated 1956, the term "forest" was defined, the lands that could not be considered forest were determined, and forests were classified in terms of their ownership and management. The prerequisite for the sustainability of the forest regime is the demarcation of the forest boundaries, performing the cadastral works, and securing it by registering it to the land registry system. With the Constitution of 1961, the principle that the ownership and management/operation of the forests would be carried out by the Government has become the basic principles of the Forest Law for the protection and sustainability of the forests. Article 131 of the Turkish Constitution of 1961 ruled that the areas that scientifically and technically lost their forest character before 15 October 1961 should be taken out of forest boundaries.

Turkish Constitution of 1982 assigned the duty of protecting forests and expanding forest lands to public institutions. The Constitution ensured that the ownership of forests belonging to the state could not be transferred. However, the following areas were allowed to be taken out of forest boundaries:

i. The lands on which preservation of forest would be of no scientific and technical benefit, even converting them into agricultural lands would provide certain benefits,

ii. The lands that scientifically and technically lost their forest character before 31 December 1981, and determined to be suitable for various agricultural purposes such as farmland, vineyard, garden, orchard, olive grove, or livestock purposes,

iii. The residential areas where city, town, or village buildings exist together.

As can be understood from Article 169 and Articles 170 of the Turkish Constitution of 1982, the forests that are guaranteed by the Constitution and the shrinkage of which are prohibited are subject to registration.

Forest demarcation is the delimitation works carried out within the scope of Forest Law No. 3116 dated 
08.02.1937. The Forest Cadastre means the determination of all real estates in the forests and adjacent to forests, and the common boundaries of the forests, as well as, the registration of these forest lands with the ownership of the Treasury (the works carried out within the scope of Forest Law No. 3116, Forest Law No. 6831, and Article 4 and Additional Article 5 of the Cadastre Law No. 3402). Taking out the areas that scientifically and technically lost their forest character in the name of Treasury (i.e. execution of Article 2/B) is also a part of forest cadastre.

With Forest Law No. 3116 dated 01.07.937, the works for demarcation (delimitation) and mapping of the forest lands were started by GDF (via the Forest Cadastre Commissions). Forest Law No. 3116 was repealed, and Forest Law No. 6831 dated 08.09.1956. With the new law, Forest Cadastre Commissions continued to the forest cadastre works for the forest lands belonging to the state, the forests that had been previously demarcated as forest but taken out of forest boundaries during the last demarcation even though it was forest land, the forests belonging to the public institutions with a legal personality, the private forests, as well as, determination of the common boundaries of all real estates in the forests and adjacent to forests.

On the other hand, with the "Law No. 1744 on the Amendment of Some Articles of the Forest Law No. 6831 and Adding a Provisional Article to this Law", which entered into force on 04.07.1973, the lands that scientifically and technically lost their forest character before 15 October 1961 began to be taken out of forest boundaries as stipulated by Article 131 of the Turkish Constitution of 1961.

With Law No. 2896 dated 23.09.1983 which amended Forest Law No. 6831, the lands that scientifically and technically lost their forest character before 31 December 1981 were continued to be taken out of forest boundaries for the settlement of all or part of the inhabitants of the villages located in the forest lands or allocation for these purposes after reclamation works carried out by the Government as stipulated by Article 169 and Article 170 of the Turkish Constitution of 1982.

With Law No. 3302 dated 05.06.1986, which also amended Forest Law No. 6831, the procedures of taking an area out of forest boundaries were carried out together with the demarcation works for the first time in forest cadastre.

The Forest Laws stipulated that technical works such as surveying and mapping during forest demarcation/cadastre would be carried out by the Forest Cadastre Commissions. However, there was no "survey engineer" in these commissions. Therefore, the forest maps prepared during the demarcation/cadastre works following Forest Laws were not produced under the responsibility of a survey engineer until 2003. Most of the forest maps produced until this year could not be registered to the land registry system due to the lack of technical quality. The forest maps that were registered directly to the land book without undergoing technical control by the cadastre directorates, also posed problems as they contained technical deficiencies.

Due to the need for legal regulations in this context, the following provisions have been introduced with the
"Law on Amending the Forest Law" No. 4999 dated 18.11.2003:

i. Technical errors detected in the lands whose cadastre procedure has been finalized shall be corrected by the Forest Cadastre Commissions,

ii. Taking aerial imagery and map production works required for cadastre and other forestry services shall be carried out by GDF,

iii. For the lands where forest demarcation or cadastre works are completed and finalized by the announcement, in case of an issue detected in terms of the acreage and technical errors arising from surveying, drawings, and calculations, except for the change of classification and ownership, these errors shall be corrected by Forest Cadastre Commissions under the notice and supervision of GDF,

iv. The correction shall be announced following Article 10 of the Law, in case of no lawsuit is filed with the civil court of peace within thirty days from the date of the announcement, the correction shall be finalized.

v. The lapse of time stipulated in Article 11 shall not be applied to the corrections,

vi. Survey and cadastre engineers shall be responsible for surveying, calculating, drawing, and application work in the preparation of the maps of forests whose cadastre is completed, and these maps, which are produced following the cadastral technical standards, shall be approved by the head of the commission after the control by the survey and cadastre engineers.

With Law No. 6292 dated 19.04.2012, an additional paragraph was added to Article 10 of Law No. 6831. This paragraph states that "Surveying, calculation, drawing, and application works for the preparation of maps of forests whose cadastre works are completed or ongoing shall be carried out by survey and cadastre engineers or technicians; the responsibility shall belong to the survey and cadastre engineers; a control engineer shall be assigned by the local directorate of GDLRC to ensure that the surveying and mapping procedures conducted in the field are carried out duly and to control and approve these works; the maps, which are produced following the cadastral technical standards, shall be approved by the head of the commission after the control approval of the survey and cadastre engineers".

Law No. 7139 dated 19.04.2018 also amended the Forest Law No. 6831. This amendment states that the Forest Cadastre Commissions shall be organized with a head of a forest engineer appointed by GDF and three members including a forest engineer, or a forest technician in case of their absence, an agricultural engineer, or an agricultural technician in case of their absence, and a representative to be notified by the municipal committee in the towns and by the village head (mukhtar) in the neighbourhoods and villages. Also, Article 10 of Law No. 7139 amended the seventh clause of Paragraph 7 of Article 9 of the Forest Law No. 6831. This amendment stipulates that the correction shall be finalized in case of no lawsuit is filed to the cadastral 
courts or courts responsible for the cadastral cases where there are no cadastral courts for the cancellation of the correction within thirty days from the date of the announcement.

\subsection{Laws and Regulations on Land Registry and Cadastre Procedures}

GDLRC, which is affiliated with the Ministry of Environment and Urbanization, has been carrying property cadastre procedures since 1925 until today as per the following laws: Cadastre Law No. 658 dated 1925, Cadastre and Land Registration Law No. 2613 dated 1937, Land Registration Law No. 5602 dated 1950, Land Registration Law No. 509 dated 1964, Law No. 766 dated 1966, and Cadastre Law No. 3402 dated 21.07.1987; however, Law No. 2613 and Law No. 766 were repealed upon need.

As per Law No. 2613 dated 1934, demarcation of the forest lands and their cadastre were excluded from the scope of the cadastral procedure of the real estates located in the central municipalities of the provinces and districts.

The Land Registration Law No. 5602 dated 1950, and the Land Registration Law No. 766, which entered into force in 1966 and was in force until 10 October 1987, were introduced to establish the land registration stipulated in the Civil Code. These laws stated that they could not be applied in forest lands. Article 2 of the Land Registry Law No. 766 stipulates that " Unclaimed lands that are not suitable for agriculture and unclaimed rocks, hills, mountains with the same character, and the lands deemed forests under the Forest Law shall not be subject to registration". Therefore, the forests that have not yet been subjected to forest cadastre by GDF were excluded from the scope of the cadastral finalization works carried out by GDLRC until Law No. 3402 dated 1987.

However, because the boundaries of the forest lands were not certain, several objections were made about the finalization of those lands, the works dragged on; as a result, the required efficiency could not be achieved. Therefore, a meeting was held with the participation of the representatives of the State Planning Organization (SPO), GDF, and GDLRC to overcome the problems in the demarcation of the forest boundary and ownership of real estates in these lands, to accelerate the work by taking joint administrative and technical measures, and to improve the work efficiency. As a result of this meeting, a protocol was signed between GDLRC and GDF on 18.03.1965. Then, GDLRC published the circular numbered 4-1-1-7.1391 and dated 09.07.1965. In this circular, the works to be carried out and the measures to be taken by both institutions regarding the forest lands in the villages to be subjected to the rural cadastre were explained.

The Cadastre Law No. 3402 was introduced in 1987 to complete cadastral works quickly and without interruption and to prevent unnecessary financial losses and waste of labour by causing duplicate works with different practices carried out by various institutions. Article 4 of Law No. 3402 stipulated the following provisions: i. In case of forest land that is not demarcated or subjected to forest cadastre in the cadastral area, the situation shall be reported to GDF two months before starting the cadastral work,

ii. The procedures of forest demarcation and taking areas out of forest boundaries shall be carried out by forest cadastre commissions as per Forest Law No. 6831. Forest cadastre commissions shall finalize the procedures and mark them on the map and deliver them together with their records to the cadastral teams.

iii. Cadastre teams shall complete surveying and mapping works of these lands based on the abovementioned boundaries,

iv. In case the forest boundaries cannot be demarcated by the forest cadastre commissions within two months, the boundaries of the cadastral area shall be determined by the cadastral teams,

v. In the places finalized and announced by the cadastral teams in this way, the forest cadastre procedures shall be deemed to have been completed, these boundaries shall be strictly observed in places where the forest cadastre is finalized.

This practice continued until 2005 when a new regulation was introduced on this issue. In 2005, with the amendment made in Article 4 of the Cadastre Law No. 3402, the following provisions were stipulated:

i. In case there is forest land in the cadastre project area and the forest cadastre per Forest Law No. 6831 has not been started, the cadastral team shall carry out the forest cadastre and determine the common boundaries of all kinds of real estates in these forests and adjacent to these forests and finalize them.

ii. In these works, at least one forest engineer to be assigned by the provincial organization of the GDF and an agricultural engineer to be assigned by the Agricultural Directorates shall participate in the cadastral team within seven days from the notification.

iii. In case the village head (mukhtar) and expert witness do not participate in these works, the works shall be continued ex officio,

iv. In the examination of the objections made about the forest, a forest engineer to be assigned by the provincial organization of the GDF and an agricultural engineer to be assigned by the Agricultural Directorate, who have not taken part in the finalization work subject to objection, shall participate in the cadastral commission,

v. The demarcation of the forests in the cadastre project area and their finalization shall be made by this team, and it shall be partly announced for thirty days.

vi. The forest cadastre in these places shall be deemed to have been made, and these boundaries shall be followed exactly where the forest cadastre is finalized. 
The additional Article 5 added to the Cadastre Law No. 3402 in 2013 stipulated that the forests that were not demarcated or did not undergo forest cadastre within the project areas where cadastre or rural cadastre works were completed should be subject to cadastre within the framework of the principles stated in Articles 4 and 39.

The following provisions were introduced with the paragraphs added to Article 4 of the Cadastral Law No. 3402 in 2018:

i. In case of detection of incompatibility between records, sheet, and ground requiring correction in forest maps that are finalized after forest demarcation or cadastre, regardless of whether it is registered to the land registry system or not, the cadastre team to be formed with the participation of at least one forest engineer to be assigned by the related forestry directorate and a control engineer or engineer to be assigned by the cadastre directorate as per Article 3 of this Law shall apply the boundary points and lines of the forest to the ground based on the forest cadastre records,

ii. The detected incompatibility shall be corrected following the technical regulations by the abovementioned cadastral team organized; at the end of the work, a report shall be prepared, and this report shall be signed together by the team members and the forest and cadastre engineers.

iii. The correction procedure shall be finalized following the announcement to be made as per Article 11 of this Law,

iv. Provided that GDLRC obtain the approval of the Ministry with which it is affiliated and the costs of such works are paid by GDF to the account of GDLRC Revolving Fund, GDLRC may also have some or all of the technical parts of such works done by natural or legal persons by way of tenders, and these tenders shall allow making commitments for the next years.

\section{USE OF TECHNOLOGY}

In the forest cadastre works, compass tacheometry method (1937-1964), photogrammetric method (19651982), terrestrial surveying methods (1982), and GPS method (1998) were used from past to present (Döner and Özdemir 2016).

As per Law No. 6831, theodolites were started to be used in the forest cadastre works after 1960 (Tüdeş and Biylk 1997). In the survey method, the starting point was selected from certain points; however, the sequential boundaries of the forests, instead of the district boundaries, were taken this time. To complete the surveying of the boundaries of the forest more quickly, the angles were measured using a theodolite in grades, and distances were measured using a levelling rod in the traverse surveying according to those days' technology. The polygonal chains obtained were not connected to the national triangulation network. A specific point of the village or town, such as a mosque or a school, was taken as a reference, and the boundaries were ditched in the field; however, they disappeared over time. The collapse or displacement of buildings, which were deemed fixed and stationary points, did not often allow the demarcation map correctly to the ground (Ayanaoğlu 1992). This method was abandoned after using aerial photographs in mapping.

Then, the Photogrammetry Method, which is defined as "Photo interpretation and manual marking of forest lands into aerial photographs with $60 \%$ overlapping under stereoscopic view", was used. The aerial photographs marked in this way were evaluated using photogrammetry devices and transferred to $10 \mathrm{~K}$-scale maps obtained from $25 \mathrm{~K}$-scale standard topographic maps by using photomechanical methods. Later, this method, which aimed to demarcate the boundaries of forests quickly, brought about the issue of producing maps without technical quality.

The above-mentioned method was also used in the "Forest Cadastre" works within the scope of Law No. 1744. In addition to this method, the forest cadastre works were carried out using the images of 5K-scale Standard Topographic Maps and Standard Topographic Cadastral Maps showing integrity with the land in places where these maps were already produced. Also, the forest cadastre works were carried out by marking the parcels surveyed using the terrestrial surveying method on $10 \mathrm{~K}$ - and $5 \mathrm{~K}$-scale maps.

All of the above-mentioned methods were abandoned as of 1983. Moreover, the principle of performing forest cadastre works using the terrestrial surveying method has been adopted since then. In case the forest cadastre or forest demarcation was to be re-marked (application) on the ground, it was suggested as the main principle that the work would be renewed by using the same technique and tools that had been used in the previous work.

The Technical Circular on the Forest Cadastre, which entered into force in 1997, aimed to ensure unity and solidarity in the forest cadastre works and procedure, implementation of Article 2/B of the Forest Law No. 6831, and implementation of Article 4 of the Cadastral Law No. 3402. In this framework, the terrestrial surveying method was used as the main surveying method to demarcate the borders of the forests. However, the use of aerial photographs was permitted if they complied with the principles specified in the Regulation on the Production of Large-Scale Maps. Moreover, the Circular dated 2014 allowed the use of the GPS method in surveys. Now, the Regulation on the Production of Large-Scale Maps and Map Information and the current "Technical Circular on the Forest Cadastre" are followed in the forest cadastre works.

\section{SOLUTION METHODOLOGY}

\subsection{Collaboration}

GDLRC has started the initial cadastre works in 1925, and GDF has started the forest cadastre works in 1934. However, the performance of the cadastre works by two institutions has brought about several problems since then.

Several problems were faced in the registration of the forest maps produced by the Forest Cadastre Commissions since they did not employ a survey engineer and these maps did not comply with the 
technical standards. Therefore, some of the forest cadastre works could not be registered by GDLRC. Another problem was that the technical errors could not be corrected by GDF without a judicial decision (as well as the lack of a legal regulation on this issue).

Another issue was that the number and the organization of the teams and the cadastral activities (initial cadastre and forest cadastre activities) of both institutions were different. Therefore, the works could not be carried out synchronously, which caused duplications.

Two actions were taken to eliminate these problems. Firstly, employing a survey engineer to the forest cadastre commissions was decided to eliminate the technical errors in the forest maps under the responsibility of the survey engineer. However, the number of forest cadastre commissions was another issue even they were supported by employing a survey engineer. Therefore, the second effective formula was decided to increase the number of forest cadastre commissions to facilitate completing the forest cadastre works throughout the country. The best formula to solve this problem was the combination of the resources of GDF, as an expert institution in forestry, and GDLRC, as an expert institution in mapping. It was concluded that the collaboration environment should be provided for both institutions to carry out this work together.

Thus, carrying out the works with an understanding of 'collaboration' by mutual transfer of resources and staff (assignment) was decided to be an effective solution. Therefore, several fundamental and radical amendments were made in both Forest Law No. 6831 and the Cadastre Law No. 3402 in 2003, 2005, 2013, and 2018. These amendments could be considered reforms required for the needs of the time.

\subsection{Establishment of the Legal Infrastructure}

Until 2003, the Forest Laws stipulated that technical works such as surveying and mapping in the forest demarcation/cadastre should be carried out by the Forest Cadastre Commissions. Since these commissions had no "survey engineer" within their organizations, the forest maps were prepared according to forest demarcation/cadastre, which was not carried out under the responsibility of a survey engineer. Moreover, since most of these maps lacked technical accuracy, several challenges were faced in the registration. Law No. 4999 on the Amendment of the Forest Law dated 18.11.2003, stipulated that the correction of the technical errors detected in the finalized cadastre should be carried out by the Forest Cadastre Commissions for the solution of this problematic issue (for the lands where forest demarcation or cadastre works are completed and finalized by the announcement, in case of an issue detected in terms of the acreage and technical errors arising from surveying, drawings, and calculations, except for the change of classification and ownership). After the first step was taken for correcting the technical mistakes in forest maps, a further step was taken in 'collaboration'. This time, Article 3 of Law No. 5831 dated 15.01.2009 stipulated the following provisions: "In the places where cadastre works started as per Cadastre Law
No. 3402, in case of acreage errors arising from the calculations is detected during the control of the previously finalized forest maps, these errors shall be corrected by the cadastral team formed as per Article 4 of the Law No. 3402. In case of other issues in terms of the acreage and technical errors arising from surveying, drawings, and calculations, except for the change of classification and ownership, the Cadastral Directorate shall report the issue to the local forest directorate. A forest cadastre commission shall be assigned within 15 days from the date of notification and the correction shall be announced".

Then, Paragraph 10 of Article 11 of Law No. 6292 dated 19.04.2012 was repealed by Article 54 of Law No. 7139 dated 19.04.2018. Also, as per Article 35 of this Law, Paragraph 13 and Paragraph 14 were added to Article 4 of Law No. 3402. These paragraphs stipulated the following provisions:

i. "In case of detection of incompatibility between records, sheet, and ground requiring correction in forest maps that are finalized after forest demarcation or cadastre, regardless of whether it is registered to the land registry system or not, the cadastre team to be formed with the participation of at least one forest engineer to be assigned by the related forestry directorate and a control engineer or engineer to be assigned by the cadastre directorate following Article 3 of this Law shall apply the boundary points and lines of the forest to the ground based on forest cadastre records,

ii. The detected incompatibility shall be corrected following the technical regulations by the abovementioned cadastre team to be organized; at the end of the work, a report shall be prepared, and this report shall be signed together by the team members and the forest and cadastre engineers. The correction procedure shall be finalized following the announcement to be made as per Article 11 of this Law,

iii. Provided that GDLRC obtain the approval of the Ministry with which it is affiliated and the costs of such works are paid by GDF to the account of GDLRC Revolving Fund, GDLRC may also have some or all of the technical parts of such works done by natural or legal persons by way of tenders, and these tenders shall allow making commitments for the next years.

Thus, the technical errors in forest maps could be corrected by the forest cadastre commissions, as well as, by the cadastre team to be formed by GDLRC with the participation of a forest engineer from the GDF and a control engineer from the cadastre directorate.

An additional paragraph was added to Article 10 of Law No. 6831 as per Article 13 of Law No. 6292 dated 19.04.2012. This additional paragraph states that "Surveying, calculation, drawing, and survey applications for the preparation of maps of forests whose cadastre works are completed or ongoing shall be carried out by survey and cadastre engineers or technicians; the responsibility shall belong to the survey and cadastral engineers; a control engineer shall be assigned by the 
provincial directorate of GDLRC to ensure that the surveying and mapping procedures conducted in the field are carried out duly and to control and approve these works; the maps, which are produced following the cadastral technical standards, shall be approved by the head of the commission after the control approval of the survey and cadastre engineers".

Moreover, an additional paragraph was added to Article 10 of Law No. 6831 as per Article 13 of Law No. 6292. This additional paragraph stipulated that "Surveying, calculation, drawing, and application works for the preparation of maps of forests whose cadastre works are completed or ongoing shall be carried out by survey and cadastre engineers or technicians; the responsibility shall belong to the survey and cadastre engineers; a control engineer shall be assigned by the local directorate of GDLRC to ensure that the surveying and mapping procedures conducted in the field are carried out duly and to control and approve these works; the maps, which are produced following the cadastral technical standards, shall be approved by the head of the commission after the control approval of the survey and cadastre engineers".

Collaboration between the two institutions can be achieved in two ways. In the first option, in case the technical errors in forest maps are corrected by forest cadastre commissions, a control engineer from GDLRC may involve in the correction procedure. In the second option, in the forest cadastre works to be carried out by forest cadastre commissions, the surveying, calculation, drawing, and application work for the preparation of forest maps are carried out by the survey engineers or technicians to be assigned by the related cadastre directorate.

GDLRC has been carrying out forest cadastre during the initial cadastre works since 2005 (Article 4 of Law No. 3402). Moreover, GDLRC has been carrying out forest cadastre for the forest lands that were not finalized during the initial cadastre works completed in the villages or quarters since 2013 (Additional Article 5 of Law No. 3402). In these works, a forest engineer from GDF and an agricultural engineer from the agricultural directorate participated in the cadastre team.

\subsection{Use of Technology}

The amendments made to the laws in 2004 and 2005 introduced radical changes in both forest cadastre and general cadastral activities carried out by GDLRC. With these changes, the task of demarcating the forest boundaries in places that did not undergo cadastre was assigned to the GDLRC cadastre teams. It was stipulated that at least one forest engineer from the GDF and an agricultural engineer from the agricultural directorate should be assigned to these teams. Thus, GDF personnel participated in the cadastral works carried out by GDLRC in 3,000 villages since 2006 as per Law No. 3402 .

GDF established GPS Teams in 8 Regional Directorates of Forestry for supporting all Forest Cadastre Commissions, densification of the triangulation network, and digitization of forest cadastral maps. Also, a control system based on a database was developed and put into practice. Moreover, a geographic information system-based map server was also put into service for the first time on a portal on the official website of GDF. Technical Circular on Forest Cadastre was prepared again to harmonize sub-regulations in line with the amendments in the laws considering the current techniques and technologies specified in the amended Regulation on the Production of Large-Scale Maps and Map Information in 2005.

As of 2014, great progress has been achieved by adopting the following approach in the Technical Specification for the Production of Forest Maps: "All kinds of coordinates shall be produced based on the latest version of Turkish National Fundamental GNSS Network (TUTGA), and $1 / 5000$ scale digital photogrammetric vector maps and orthophotos shall be georeferenced with the Universal Transverse Mercator (UTM) projection with 3-degree zones using GRS80 ellipsoid and ITRF96 Datum. The digital data to be produced shall meet the standards specified in the relevant articles of the Regulation on the Production of Large-Scale Maps and the draft Regulation on the Production of Large-Scale Maps and Map Information.

On the other hand, GDLRC used the Regulation on the Production of Large-Scale Maps and the circulars published by the institution on the GNSS (Global Navigation Satellite System) surveying, calculation, and control, which are not addressed in the regulation.

With the widespread use of the CORS-TR (Continuously Operating Reference Stations) project, both institutions began to use it in 2009. Since CORS-TR has become the national fundamental infrastructure in geospatial projects, it has been widely used by all institutions and organizations. Also, geographical information systems applications have been widely used for creating the spatial data infrastructure in both institutions. With these technological developments, both GDLRC and GDF began to produce and share digital geospatial data.

\section{RESULTS}

Several significant factors caused the problems experienced for years in forest cadastre. The first factor was that the cadastre was classified as forest cadastre and property cadastre, and they were carried out by different institutions. The second factor was the technologies used in the cadastre works; although they were widely used in those days, they were obsolete today. Another factor was the complex structure of regulations due to frequent amendments due to needs.

The solution to the problem was achieved by giving priority to the completion of the property cadastre for meeting the investment priorities for the development of the country and the evolving needs with the conditions of the day, as well as, to solve the ongoing problems about forest lands and other property problems that arose in the following years due to these problems (such as ownership, acquisition, possession/occupation, real estate boundaries belonging to real persons, as well as, disputes about the property boundaries, zoning, settlement, land consolidation, energy projects, dam construction, infrastructure, agriculture, pasture, Article 
2/B applications, renewal, technical error correction, etc.).

Forest cadastre was carried out by cadastre teams following Article 4 of the Cadastre Law No. 3402 during the initial cadastre, which was carried out following this Law. Then, it was carried out by forest cadastre commissions following Forest Law No. 6831.

As per Law No. 6495, Additional Article 5 was added to Law No. 3402. With this amendment, cadastre teams (with the participation of a forest engineer and an agricultural engineer as stipulated by Article 4 of Law No. 3402) have begun to carry out all forest cadastre works.

The collaboration between institutions was achieved based on the idea to eventually register the forest cadastre, and the required regulation amendments were made. Within the scope of the solution methodology, the approach of the participation of the private sector in forest cadastre works was adopted for digital and quick cadastre.

Therefore, the technical parts of the cadastre works were given out by contracts to the private sector by GDLRC under the coordination of both institutions. This outsourcing approach accelerated the projects through the use of modern technology.

Table 1 shows the distribution of forest cadastre and registration completed in recent years (TFA 2019). The history of the forest cadastre in Turkey started with Law No. 3116 in 1937. By 1973, only 4,558,000 hectares of the forests could undergo cadastre procedure. Between 1937 and 2004, only $51.8 \%$ of the forests could undergo cadastre procedure, and only $19.38 \%$ of the forests could be registered. However, thanks to the collaboration between the institutions and the use of the private sector, the forest cadastre of the remaining $48.2 \%$ and the registration of $60.2 \%$ were completed between 2010 and 2017. As of 2018, the forest cadastre of $24,000,000$ hectares of forest has been completed, and 19,806,000 hectares of forest were registered. Registration works continue for forests that have not been registered yet.

Table 1. Forest lands that underwent forest cadastre and were registered

\begin{tabular}{ccclc}
\hline Year & \multicolumn{2}{l}{$\begin{array}{l}\text { Acreage of the forest } \\
\text { lands that underwent } \\
\text { forest cadastre }\end{array}$} & $\begin{array}{l}\text { Acreage of the Forest } \\
\text { lands that were } \\
\text { registered }\end{array}$ \\
\cline { 2 - 5 } & $\begin{array}{c}\text { Cumulative } \\
\text { acreage } \\
\text { (ha) }\end{array}$ & $\begin{array}{c}\text { Increase } \\
\text { (ha) }\end{array}$ & $\begin{array}{l}\text { Cumulative } \\
\text { acreage } \\
\text { (ha) }\end{array}$ & $\begin{array}{c}\text { Increase } \\
\text { (ha) }\end{array}$ \\
\cline { 2 - 5 } 1973 & $4,558,000$ & - & $3,055,079$ & - \\
2004 & $12,446,407$ & $7,888,407$ & $4,653,000$ & $1,597,921$ \\
2010 & $17,573,155$ & $5,126,748$ & $11,824,130$ & $7,171,130$ \\
2011 & $17,746,416$ & 173,261 & $12,188,834$ & 364,704 \\
2012 & $19,073,052$ & $1,326,636$ & $16,230,739$ & $4,041,905$ \\
2013 & $19,175,273$ & 102,221 & $16,749,736$ & 518,997 \\
2014 & $20,774,691$ & $1,599,418$ & $16,950,000$ & 200,264 \\
2015 & $21,240,530$ & 465,839 & $17,799,940$ & 849,940 \\
2016 & $23,450,000$ & $2,209,470$ & $18,860,000$ & $1,060,060$ \\
2017 & $24,000,000$ & 550,000 & $19,500,000$ & 640,000 \\
2018 & - & - & $19,806,000$ & $3,506 *$ \\
\hline
\end{tabular}

*The data for 2018 are taken from the GDF official website.

As can be seen from Table 2, within the scope of forest cadastre studies, 538.005 hectares of land were removed from the forest and registered in the land registry according to the article 2-B of the Forest Law Number
6831 as of the end of 2018 (TFA 2019). According to the 2020 report of the National Property General Directorate, 581,000 of the registered parcels were taken out of the forest and sold to their users (NREB'20).

Table 2. Forest lands that the areas taken out of forest boundaries

\begin{tabular}{lcc} 
Year & \multicolumn{2}{l}{$\begin{array}{l}\text { Acreage of the areas taken out of } \\
\text { forest boundaries }\end{array}$} \\
\cline { 2 - 3 } & $\begin{array}{l}\text { Cumulative } \\
\text { acreage (ha) }\end{array}$ & Increase (ha) \\
& - & - \\
1973 & 341.521 & 341.521 \\
2004 & 411.843 & 70.322 \\
2010 & 432.397 & 20.554 \\
2011 & 439.473 & 7.076 \\
2012 & 450.461 & 10.988 \\
2014 & 473.081 & 22.620 \\
2015 & 483.155 & 10.074 \\
2016 & 502.000 & 18.845 \\
2017 & 535.598 & 33.598 \\
2018 & 538.005 & 2.407 \\
\hline
\end{tabular}

\section{CONCLUSION}

Cadastre Law No. 3402 aims to determine the legal status of real estates by marking their boundaries on the ground and map according to the national coordinate system and based on the cadastral maps or topographic cadastral maps. Thus, the land registry shall be established as stipulated by the Turkish Civil Code No. 4721, and the spatial information system infrastructure shall be established. Cadastre Law No. 3402 does not classify the cadastre of the real estates as property cadastre, forest cadastre, pasture cadastre, agricultural cadastre, etc. In other words, this law aims to determine the technical and legal status of real estates through cadastre and to establish their land registry accordingly.

Collaboration was achieved between the two institutions engaged in property cadastre and forest cadastre by establishing legal and technical infrastructures within the framework of the definition of Cadastre.

Thanks to the participation of the private sector, the forest cadastre was completed in digital format and in a very short time between 2010 and 2017 at the end of the project. Moreover, the registration of $82.52 \%$ of these lands was completed. Effective and efficient use of public resources has been through collaboration. However, a major social problem was solved by making cadastre of the areas taken out from the forest and these parcels were sold to the users.

In addition to these achievements, a model compatible with the UN Agenda 2030, Digital Transformation, Sustainable Development Goals has been created. This model sets an example for other countries experiencing similar problems within the framework of Goal 15.

\section{Author Contributions:}

Orhan Ercan: Conceived the original idea, made a significant contribution to the concept and took the lead in writing the manuscript. Kemalettin Toker: Helped 
shape the research, analysis and manuscript, discussed the results and contributed to the final manuscript.

\section{Conflicts of interest}

The authors declare no conflicts of interest.

\section{REFERENCES}

Anbar Ö A, (2004). Orman Tahdit Haritaları Doğrultusunda Tapu ve Kadastro İşlemleri (Land Registry and Cadastre Procedures in Line with Forest Delimitation Maps), HKMO Orman Kadastrosu ve 2/B Sorunu Sempozyumu, 17-18 Eylül 2004

Ayanoğlu S (1992). Genel Kadastro-Orman Kadastrosu İlişkileri Üzerinde İncelemeler (Eng: Studies on General Cadastre-Forest Cadastre Relations), Journal of the Faculty of Forestry, Istanbul University, Seri B, Cilt: 42, Sayı: 3- 4, 1992

Cadastre and Land Registration Law No. 2613 dated 1937,

Cadastre Law No. 3402 dated 21.07.1987

Cadastre Law No. 658 dated 1925,

Çağlar Y (2004). 2B Olgusunun Tarihsel ve Nesnel Boyutları (Historical and Objective Dimensions of the 2B Fact), HKMO Orman Kadastrosu ve 2/B Sorunu Sempozyumu, 17-18 Eylül 2004

Döner F \& Özdemir F (2016). Orman Kadastrosu Çalışmalarında Ölçme İşleri (Surveying Works in Forest Cadastre Studies), HKMO-Mühendislik Ölçmeleri STB Komisyonu 8. Ulusal Mühendislik Ölçmeleri Sempozyumu 19-21 Ekim 2016, Yıldız Teknik Üniversitesi, İstanbul

FAO (2015), Global Forest Resources Assessment 2015, Country Report

Forest Law No. 3116 and Laws No. 4785, 5653 and 5658 Amending this Law

Forest Law No. 6831

Gençay G (2012). Orman Kadastrosunun Güncel Sorunları Üzerinde Hukuksal İncelemeler (Legal Reviews on Current Problems of Forest Cadastre), Journal of the Faculty of Forestry, Istanbul University 2012, 62 (2): 173-195

Köktürk E (2004). Orman Kadastrosu (Forest Cadastre), Jeodezi, Jeoinformasyon ve Arazi Yönetimi Dergisi, 2004/91

Land Registration Law No. 509 dated 1964,
Land Registration Law No. 5602 dated 1950,

Livia B L, Costel B, Gabriel E, Nicoleta C (2010). Implementing the Forest Cadastre by Applying the Property Law in Order to Register A Forest Plot, FORMEC 2010 Forest Engineering: Meeting the Needs of the Society and the Environment July 11 - 14, 2010, Padova - Italy

Milli Emlak Bülteni '20 (2021), Çevre ve Şehircilik Bakanlığı, Ankara, 2021 (NREB'21, Ministry of Environment and Urbanization, National Property Bulletin '20, Ankara 2021)

Orman Genel Müdürlüğü 2006 Yılı Faaliyet Raporu (General Directorate of Forestry 2006 Annual Report) Orman Genel Müdürlügü 2011 Yılı Faaliyet Raporu (General Directorate of Forestry 2011 Annual Report)

Orman Genel Müdürlüğü 2015 Yılı Faaliyet Raporu (General Directorate of Forestry 2015 Annual Report) Orman Genel Müdürlügü 2017 Yılı Faaliyet Raporu (General Directorate of Forestry 2017 Annual Report)

Orman Genel Müdürlüğü Stratejik Plan 2010 - 2014 (General Directorate of Forestry Strategic Plan 2010 - 2014)

Orman Genel Müdürlüğü Stratejik Plan 2013 - 2017 (General Directorate of Forestry Strategic Plan 2013 - 2017)

Orman Kadastrosu Teknik İzahnamesi, 2014 (General Directorate of Forestry, Forest Cadastre Technical Prospectus, 2014)

Rural Cadastre Law No. 766 dated 1966,

Tüdeş T \& Bıyık C (1997). Kadastro Bilgisi (Cadastre), Karadeniz Teknik Üniversitesi Basımevi, İkinci Baskı, Trabzon

Türkiye Ormancılar Derneği-TOD, Türkiye Ormancılığı 2019 (The Foresters' Association of Turkey, TFA, Turkey Forestry 2019): Ankara, 2019, ISBN:978-97593478-4-0 Publication No: 47

UN (2016) Transforming our world: the 2030 Agenda for Sustainable Development, Goal 15, https://sdgs.un.org/goals/goal15

Yalçın G (2012). Forest and Cadastre in Turkey and Sustainable Development, FIG Working Week 2012, Knowing to manage the territory, protect the environment, evaluate the cultural heritage Rome, Italy, 6-10 May 2012 